\title{
Value and Approach of Intangible Cultural Heritage in Moral Education in Colleges
}

\author{
Ke Sun \\ Cultural and Social Development Research Center \\ Shandong University \\ Weihai, China 264200
}

\begin{abstract}
Intangible cultural heritage is an important part of traditional culture. Bringing it in moral education in colleges can realize humanistic return of college education and has important practical significance on moral education. Therefore, we should actively explore effective ways and integrate intangible cultural heritage in moral education to realize interaction and mutual benefit of moral education and inheritance of excellent national culture.
\end{abstract}

Keywords-intangible cultural heritage; moral education in colleges; practice approach

\section{INTRODUCTION}

Human history is created in inheritance. Cultural heritage condenses excellent cultural accumulation, moral rule, social ideal and national spirit formed for thousands of years. In the era of economic globalization and thought diversification, it's crucial to think how to regard national cultural heritage and exert its educational function. Intangible cultural heritage is dynamic heritage, the inheritance and development of which will improve college students' moral cultivation and humanistic quality. Therefore, moral education in colleges must embody the value of intangible cultural heritage and highlight "cultural education" and absorb nutrient from excellent traditional culture.

\section{DEFINITION OF INTANGIBLE CULTURAL HERITAGE}

UNESCO defines intangible cultural heritage as practice, performance, forms, knowledge system and skills regarded by groups, teams and individuals as cultural heritage and related tools, material objects, handiwork and cultural place.

Since the World Heritage Convention was issued in 1972, people have known clearly about historical heritage and natural heritage. In modern information society, strong culture erodes weak culture. People find tremendous national culture and folk culture gradually disappear. Therefore, they review cultural localization and the inheritance of traditional culture. In 2000, UNESCO established Representative List of the Intangible Cultural Heritage of Humanity, opening a new era of protection and inheritance of "intangible cultural

Fund project: China Postdoctoral Science Foundation (No. 2016M602159), Scientific Research Business Expense Project of Shandong University (No. 2015WQXM2004), the phased objective of Shandong Art Science Key Project (No. 1506381). heritage".

China is a country with an ancient civilization and has colorful "intangible cultural heritage". As an important part of cultural heritage, intangible cultural heritage represents national spirit and culture and witnesses Chinese history as well as carries excellent Chinese culture. At the meantime, it contains unique way of thinking, cultural consciousness and wisdom of Chinese nation and bears the secret of national culture. "Intangible cultural heritage" highly embodies creativity and refers to fundamental basis of national cultural identity and cultural sovereignty and embodies national spirit

"Intangible cultural heritage" represents national wisdom and civilization and cultural lifeblood of human. Feng Jicai once observed, "Like human material heritage, "intangible cultural heritage" of human is crystallization of human culture and precious wealth, referring to cultural lifeblood for human society and intangible culture, which is more important than tangible culture. "Intangible cultural heritage" includes endless emotions of human and contains profound meaning and value". [1] China has defined June 10 as "Cultural Heritage Day" since 2006; has established protection system of "intangible cultural heritage" list at national, provincial, municipal and county levels to evaluate regularly. These positive and effective measures strengthen recognition of cultural identity and cohesion.

\section{MORAL EDUCATION VALUE OF INTANGIBLE CULTURAL HERITAGE}

Intangible cultural heritage represents excellent traditional culture. Learning and inheriting "intangible cultural heritage" effectively improves college students' moral cultivation and humanistic quality, lets them experience quintessence and characteristics of traditional Chinese culture and trains their deep emotion towards national culture.

\section{A. Intangible Cultural Heritage Is an Important Carrier of National Spirit}

"Intangible cultural heritage integrates excellent traditional cultural forms and cultural space closely related to human life, national humanistic spirit, values, folk custom, language system and cultural psychology. The formation of national spirit is inseparable from "intangible cultural 
heritage". Cultures of nationalities in China impact and infuse. The quintessence part of it is regarded as national spirit, namely "unity and solidarity, independence, peace loving and ceaseless self-improvement". "Intangible cultural heritage carries Chinese national spirit, symbolizes national spirit and traditional culture, providing space for inheritance and development of national spirit. [2]

\section{B. Intangible Cultural Heritage Awakens College Students' Sense of National Identity}

As an important part of excellent national culture, "intangible cultural heritage" includes skills, verbal language arts and cultural psychology model that influence cultural life of the public. In today's globalization, different countries have prominent conflicts in values, moral principles, ideological belief, religious belief and life style. Western developed countries rapidly spread their values and life style, greatly impacting traditional moral education in China. World integration weakens contemporary college students' sense of national identity and national sovereignty consciousness as well as their national self-respect and selfconfidence. "Intangible cultural heritage" awakens college students' sense of national identity, enables them to know about historic culture created by our ancestors, in order to let them have strong sense of national identity and selfconfidence, train sound and upright moral idea and strengthen national self-esteem and self-confidence. [3]

\section{Intangible Cultural Heritage Creates College Students' National Cohesion}

"Intangible cultural heritage" integrates national humanistic spirit, values, folk customs and cultural psychology. With a history of thousands of years, although Chinese nation suffers from hardships, Chinese civilization remains powerful vitality and stands still in the world. Intangible cultural heritage carries Chinese culture. Today, Huangdi Mausoleum and Xuanyuan Temple in Shannxi are places for Chinese people to sacrifice. In Tomb-sweeping Day, people gather here and kowtow piously, manifesting the national emotion that "blood is thicker than water" and national cohesion.

\section{Intangible Cultural Heritage Trains College Students' Patriotism}

Patriotism is spiritual pillar of a nation and has value orientation and can measure national comprehensive power. Created and inherited by Chinese people, "intangible cultural heritage" gathers toil and wisdom of Chinese people for thousands of years and fully embodies excellent cultural values and aesthetic ideal. As human resources and precious artistic tradition, it plays positive role in carrying forward national spirit, stimulating patriotism enthusiasm and strengthens social cohesion and developing traditional national culture. Carrying forward and inheriting excellent "intangible cultural heritage" through effective carries in and after class makes college students love the motherland, homeland and people.

\section{PRACTICE APPROACHES TO INTEGRATE INTANGIBLE Cultural Heritage in COllege Moral EduCATION}

Moral education in colleges must innovate continuously and keep pace with the times and give students space to expand fully. In order to integrate "intangible cultural heritage" in moral education, colleges must get rid of the traditional cramming method of teaching and realize humanistic return of moral education in campus life.

\section{A. Combine Intangible Cultural Heritage with Curriculum of Moral Education}

Curriculum of moral education in colleges is important part of college education. Combining "intangible cultural heritage" with reform of curriculum of moral education is the innovation and development to integrate "intangible cultural heritage" in moral education. Colleges must integrate cultural connotation and value of times of "intangible cultural heritage" in curriculum of moral education to make it vivid and diversified, "imperceptibly" guide college students' values and behaviors and make the moral education more effective. Curriculum of moral education must be regarded as practice approach to carry forward excellent traditional Chinese culture. We must establish the value of "intangible cultural heritage" in moral education, combine modern educational concept with excellent national culture and find the common ground of "intangible cultural heritage" and "people-oriented" educational concept, in order to improve students' moral accomplishment, cultivate students' moral sentiments and experience the charm of excellent traditional culture as well as crate harmonious learning environment.

\section{B. Combine Intangible Cultural Heritage with Cultural Activity on Campus}

Integrating "intangible cultural heritage" in construction of campus culture is effective way to integrate "intangible cultural heritage" in moral education. Excellent "intangible cultural heritage" of Chinese nation is extensive and profound and attractive for college students. Therefore, in order to integrate in moral education, "intangible cultural heritage" must combine with construction of campus culture to let students feel the charm of traditional Chinese culture. At present, Chinese colleges have explored to combine "intangible cultural heritage" with cultural activity on campus. "Intangible cultural heritage" enriches the cultural connotation on campus, expands college students' extracurricular cultural life and improves their physical and mental quality as well as stimulates their enthusiasm in loving motherland and hometown.

\section{Combine Intangible Cultural Heritage with College Students' Practical Activities}

College students' practical activities are effective carrier to integrate "intangible cultural heritage" in moral education. Colleges must organize students to do investigation on "intangible cultural heritage" according to scientific research and practice, guide them to pay attention to contents and forms of "intangible cultural heritage" and excavate rich folk cultural resources and discuss affluent connotation and era 
value of "intangible cultural heritage". Students thoroughly understand local traditional folk culture and become more competent in scientific research and practical activities. Compared with traditional moral education, "intangible cultural heritage" education is more practical and operational, emphasizing practical teaching of "field work". Because "intangible cultural heritage" comes from the public, research practice makes college students contact folk life and inheritor of folk culture and experience the charm of folk culture and literature. Students have consciousness to protect "intangible cultural heritage" and develop innovation spirit and practical ability. [4] Meanwhile, colleges can help students to experience extensive and profound traditional Chinese culture and establish sense of national pride. The traditional moral education is transformed into students' selfcognition and self-education.

\section{CONCLUSION}

College students are the hard core to realize great rejuvenation of Chinese nation. Their quality and sense of national responsibility concerns the future of our nation. Under the background of diversified culture, colleges must exert the function of moral education of excellent traditional culture, explore how to exert college students' subjective initiative and strengthen sense of national identity and responsibility, in order to train college students' national spirit. [5]

"Intangible cultural heritage" contains numerous traditional cultural knowledge and skills and embodies humanistic spirit; in learning and inheriting "intangible cultural heritage", college students can develop field investigation ability and consciousness of skill inheritance as well as practical ability and theoretical analysis ability, and effectively improve humanistic accomplishment.

"Intangible cultural heritage" is precious cultural heritage and national spirit left by our ancestor. We must treasure it that carries cultural memory of Chinese people from generation to generation. We must let college students carry forward national spirit and strengthen recognition of cultural identity through understanding and inheriting "intangible cultural heritage". In moral education for college students based on the inheritance of excellent "intangible cultural heritage", colleges must fully excavate moral education resources in traditional culture and integrate it in moral education to manifest era value of "intangible cultural heritage" and realize the interaction between inheritance of "intangible cultural heritage" and college students' moral education.

\section{REFERENCES}

[1] Feng Jicai. Keep Watch the Folks [M], Beijing: Xiyuan Press, 2002

[2] Ma Yan. Cultivating College Students' National Spirit through Intangible Cultural Heritage [J], Research of Modern Young People, 2008(1): 5-8

[3] An Xuebin. Historical Value and Contemporary Habitat of National Cultural Inheritors [J], Journal of Yunnan Nationalities University: Social Sciences, 2007(11): 18-22
[4] Xu Jinlong. Current Situation of Intangible Cultural Heritage Education on College Students [J], Journal of Gannan Normal University, 2009(1), 118-121

[5] Li Benliang, Tao Zhixiang. Thinking on Cultivating College Students' National Spirit through Excellent National Culture [J], Education and Vacation, 2007(12): 133 